\title{
MODEL PEMBELAJARAN 'UNFOLD CIRCLES' UNTUK MEMBANGUN PENDIDIKAN KARAKTER DAN POTENSI ANAK DI LEMBAGA PAUD
}

\section{UNFOLD CIRCLES MODEL TO BUILD CHILDREN CHARACTERS AND POTENCIES AT EARLY CHILDHOOD EDUCATION (PAUD) INSTITUTION}

\author{
Nanik Suratmi dan Uun Munhaji \\ FKIP Universitas Kanjuruhan Malang, JI. S. Supriadi No.48, Malang, Jawa Timur \\ e-mail: naniunikama@yahoo.com
}

Naskah diterima tanggal: 08/06/2015, Direvisi akhir tanggal: 24/07/2015, disetujui tanggal: 01/08/2015

\begin{abstract}
This study aims to obtain a description of the way the Unfold Circle model has been implemented in different areas to show how this model can be used to develop and improve the competence, multiple intelligence and characters of children to show how this model can help reinstate the true function of Early Childhood Education as "a beautiful garden for children to enjoy learning by playing". This model, as a further development of the Beyond Center Circle-time's model, uses multiple methods including qualitative descriptive methods at the exploration stage and classroom action research at the application stage as the result of reflective theories. The classroom action research was conducted from March to August 2014. The results were as follows: 1) in Early Childhood Education in Kota Malang, the basic competencies and multiple intelligence of children are being developed very well, with multiple intelligence reaching the indicator of "very significant" and "significant", and the nine basic character indicators showing very good development; 2) in Early Childhood Education in Kabupaten Malang, the basic competencies and multiple intelligence of children are only reaching the indicators of "significant" and "less significant", and several characters are developing at "unsatisfactory" levels. However, spiritual intelligence appeared prominently. Overall, the learning achieved using the Unfold Circle model enabled the children to be active and enthusiastic in finishing their tasks. It is concluded that Unfold Circle Model can be exactly implemented childhood education in the urban and rural areas in the various situation and condition.
\end{abstract}

Keywords: learning model, unfold circles, early childhood education

Abstrak: Penelitian ini bertujuan untuk memperoleh gambaran hasil penerapan Model Unfold Circles di wilayah yang berbeda, membuktikan bahwa model ini mampu mengembangkan dan meningkatkan kompetensi kecerdasan dan karakter dasar anak usia dini, serta mengembalikan fungsi hakiki dari Pendidikan Anak Usia Dini sebagai 'taman yang indah untuk belajar melalui bermain'. Model pembelajaran yang merupakan pengembangan Beyond Center Circles Time ini menggunakan multi metode, yaitu deskriptif kualitatif dan penelitian tindakan kelas. Untuk tahap eksplorasi, digunakan metode deskriptif kualitatif, sedangkan pada tahap penerapan model (hasil refleksi teori) digunakan Penelitian Tindakan Kelas dan dilaksanakan pada bulan Maret sampai dengan Agustus 2014. Hasil penelitian menunjukkan: 1) untuk Pendidikan Anak Usia Dini di Kota Malang, kemampuan dasar dan kecerdasan jamak peserta didik berkembang sangat baik; dengan peningkatan kecerdasan jamak sangat signifikan dan signifikan; dan sembilan karakter muncul dan berkembang baik; 2) untuk Pendidikan Anak Usia Dini di Kabupaten Malang kemampuan dasar dan kecerdasan jamak anak berkembang baik, akan tetapi peningkatan yang terjadi hanya signifikan dan kurang signifikan; kecerdasan spiritual muncul sangat menonjol sekali, beberapa karakter berkembang kurang memuaskan. Keseluruhan proses pembelajaran dengan model Unfold Circles membuat peserta didik aktif dan antuasias dalam menyelesaikan tugas yang diberikan. Kesimpulannya yaitu model Unfold Circles secara valid dapat diterapkan pada PAUD wilayah perkotaan dan pedesaan, dalam berbagai situasi dan kondisi.

Kata Kunci: model pembelajaran, unfold circles, PAUD 


\section{PENDAHULUAN}

Di Indonesia, masalah yang paling memprihatinkan dihadapi oleh pendidikan anak usia dini (PAUD) adalah proses pembelajaran yang terjadi mirip dengan pengajaran yang diberikan pada siswa sekolah dasar. Suasana pembelajaran lebih banyak diwarnai dengan model ceramah dari pada mengusahakan berbasis bermain sebagaimana yang dibutuhkan oleh anak. Penerapan model seperti ini menyebabkan kreativitas anak sering diintervensi oleh para guru, sehingga mereka hanya menjadi robot (Sumarni, 2013). Guru PAUD umumnya tidak menyadari bahwa pembelajaran seperti ini dapat menghambat perkembangan kompetensi dasar dan juga kecerdasan jamak anak usia dini (AUD), yaitu individu yang masih berada dalam masa kritis dan sangat peka terhadap efekefek pengaruh lingkungan tertentu (Lower dan Cassidy, 2007). Hal ini dapat terjadi karena kebanyakan guru PAUD, terlebih di daerah pedesaan, kompetensi profesional untuk mengajar AUD kurang memadai. Keterbatasan pengetahuan dan informasi yang dimiliki guru dapat menyebabkan potensi anak tidak berkembang optimal (Hedges, 2014; Rahman, 2013).

Walaupun dalam Permendiknas RI Nomor 19 tahun 2005 pasal 29 tentang Standar Pendidikan Nasional menjelaskan bahwa standar minimal bagi pendidik PAUD adalah D-IV atau Sarjana S1, namun masih banyak pendidikan guru PAUD yang berada di bawah standar tersebut. Hasil penelitian Suratmi (2013) menggambarkan pendidikan guru PAUD Kota dan Kabupaten Malang yang masih rendah, dan berimbas pada kompetensi profesional mereka.

Montessori (2008), ahli pendidikan anak tingkat dunia, menyatakan bahwa AUD pada tahun-tahun awal, memiliki periode-periode yang sensitif untuk mempelajari atau berlatih sesuatu, yang disebut 'Golden Age' (Baskett, Bryant, White dan Rhoas, 2007; Chien, Howes, Carollee; Burchinal, Margaret; Pianta, Robert; Bryant, Donna, 2010). Setiap anak dilahirkan dengan membawa sejumlah potensi yang disebut dengan kecerdasan jamak (multiple inteligences). Menurut Aminatun (2008), Gardner mengemukakan 9 kategori inteligensi yaitu: linguistic intelligence; logical intelligence; spatial intelligence; kinesthetic intelligence; musical intelligence, inter \& intra-personal intelligence; naturalistic intelligence dan existential intelligence. Proses pembelajaran di PAUD harus mampu mengembangkan 9 kecerdasan tersebut, dan sebagai bentuk perlakuan yang diberikan harus pula memperhatikan karakteristik yang dimiliki pada setiap tahapan perkembangan anak (Putra, 2012). Pendidikan pada tahap ini memfokuskan pada physical, intelligence/cognitive, emotional dan social education (Drzal, Carenno, Li-Grining, 2008; Guo, Piasta, Justice dan Kaderavek, 2010)

Kementerian Pendidikan Nasional telah mewajibkan penanaman nilai-nilai karakter dimulai dari PAUD. Melalui lembaga ini, guru dapat membangun moral bangsa, sikap dan karakter generasi muda kita sejak dini (Departemen Pendidikan Nasional, 2013). Pembentukan karakter bangsa dan kehandalan sumber daya manusia ditentukan oleh perlakuan yang tepat kepada anak sedini mungkin. Hal ini dikarenakan pembelajaran di PAUD menentukan perkembangan anak selanjutnya dan merupakan fondasi dasar pembentukan kepribadian anak (Vartuli dkk, 2014; Hedges, 2014). Terdapat 9 karakter dasar yang diwajibkan untuk pendidikan nasional untuk dibentuk dan dikembangkan di PAUD, yaitu: (1) cinta Tuhan, bersyukur, dan cinta kebenaran; (2) kemandirian, disiplin, tanggung jawab; (3) jujur, amanah, berkata bijak; (4) sopan, hormat, patuh, pendengar yang baik; (5) dermawan, suka menolong, kerja sama; (6) percaya diri, kreatif, pantang menyerah; (7) baik, rendah hati; (8) kepemimpinan, keadilan; (9) toleransi, kedamaian, kedermawanan (Departemen Pendidikan Nasional, 2013).

Anak usia dini adalah anak yang berumur 0-6 tahun (UU No. 20/2003), termasuk di dalamnya adalah peserta didik Taman Kanakkanak (TK) yang berusia 4 - 5 tahun (Yuliani, 2009). Mereka sering disebut anak pra sekolah, 
yang memiliki masa peka (sensitif) dalam perkembangannya, dan terjadi pematangan fungsi-fungsi fisik dan psikis yang siap merespons stimulasi lingkungan dan menginternalisasikan ke dalam pribadinya. Elliot (Moss dan Dahlberg, 2008) menyatakan bahwa masa ini merupakan yang paling tepat untuk meletakan dasar pertama dan utama dalam mengembangkan berbagai potensi dan kemampuan fisik, konitif, bahasa, seni, socialemosional, spiritual, konsep diri, disiplin diri dan kemandirian. Untuk mengembangkan kebutuhan anak dibutuhkan guru yang kreatif dengan kompetensi profesional yang memadai (Drzal dkk., 2008)

Hasil penelitian Suratmi (2013) mendaati bahwa selain keterbatasan kemampuan guru, terdapat kendala lain yang hampir terjadi di semua PAUD di Indonesia, yaitu rata-rata PAUD mempunyai peserta didik lebih dari 35 anak/ kelas. Besarnya jumlah peserta didik yang hanya didampingi 2 guru, maka guru menjadi kurang maksimal dalam mengamati perkembangan anak. Untuk itu dibutuhkan suatu kondisi pembelajaran yang menyenangkan, yang mampu menstimuli semua kebutuhan anak agar pertumbuhan dan perkembangan anak tercapai secara optimal. Semua perkembangan ini dapat tercapai dalam implementasi pembelajaran yang aktif kreatif dan enjoy learning. Seperti yang diungkapkan oleh Hedges (2014) bahwa anak belajar melalui pengalaman keseharian mereka dengan orangorang yang mereka sayangi dan percayai, serta proses pembelajaran yang mereka ikut terasa menyenangkan.

Dengan demikian, maka permasalahan penelitian ini difokuskan pada: (1) gambaran dampak tidak memadainya kompetensi profesional guru PAUD pada wilayah yang berbeda situasi dan kondisinya; (2) aspek-aspek kecerdasan jamak, kemampuan dasar dan karakter yang dapat dikembangkan dalam penerapan model Unfold Circles di wilayah yang berbeda situasi dan kondisinya; (3) penerapan model Unfold Circles mampu mencerminkan pembelajaran enjoy learning bagi AUD.

\section{KAJIAN LITERATUR \\ Dasar Pengembangan Unfold Circles}

Untuk mengembalikan fungsi Taman kanakkanak seperti tujuan semula yaitu Taman Kanak-kanak adalah taman bermain tanpa tuntutan apa-apa, penulis mengembangkan model Beyond Center and Circle Time (BCCT), yaitu model pembelajaran AUD yang dikembangkan oleh Creative Center for Childhood Research di Florida USA. Secara sederhana model BCCT merupakan strategi pembelajaran dengan konsep belajar dimana guru menghadirkan dunia nyata ke dalam kelas dan mendorong anak membuat hubungan antara pengetahuan yang dimlikinya dengan menerapkannya dalam kehidupan sehari-hari (Lestarini, 2013).

Sayangnya, di Indonesia model ini sulit diterapkan di PAUD karena memerlukan dana besar dan lahan luas. Demikian juga dengan rasio perbandingan guru/peserta didik yang hanya 1 guru/5 anak (Lestarini, 2013; Rahman, 2013). Berdasarkan kenyataan ini, maka BCCT dikembangkan menjadi model Unfold Circles, sebagai model pembelajaran AUD berbasis kondisi dan situasi di mana PAUD berada, serta dapat membentuk karakter sesuai dengan yang diwajibkan Diknas.

Dengan mengembangkan BCCT menjadi Unfold Circles diharapkan bahwa hasil pengembangan terhadap output PAUD adalah anak mampu memperoleh pengetahuan dari konteks yang terbatas, sedikit demi sedikit, dan dari proses yang dilakukan dan dicoba sendiri, sebagai bekal untuk memecahkan masalah dalam kehidupannya sebagai anggota masyarakat dan masa yang akan datang (jangka panjang). Dalam mengembangkan model Unfold Circles, filosofi Konstruktivisme menjadi landasan utama. Moss dan Dahlberg (2008) berpendapat, pendekatan konstruktivisme bertolak dari suatu keyakinan bahwa belajar adalah membangun (to construct) pengetahuan itu sendiri, setelah dicernakan dan dipahami dalam diri individu, dan merupakan perbuatan dari dalam diri seseorang. Dalam perilaku belajar, yang terpenting adalah bagaimana mempergunakan peralatan mental 
untuk menguasai apa yang dipelajari. Pengetahuan itu diciptakan kembali dan dibangun dari dalam diri seseorang melalui pengamatan, pengalaman dan pemahamannya. Kesalahan atau ketidakmampuan anak merupakan bagian dari belajar, jadi harus dihargai. Disinilah tugas guru untuk memberikan bantuan (scaffolding) sebagai fasilitator dan pembimbing.

Stefanakis (CCCRT, 2007) mengutip pernyataan Lev Vygotsky, seorang socialcultural constructivist, yang menyatakan bahwa pengetahuan tidak diperoleh dengan cara dialihkan dari orang lain, melainkan merupakan suatu yang dibangun dari pengalaman dan diciptakan oleh anak. Selanjutnya melalui teori revolusi sosio kulturalnya, Vygotsky mengemukakan bahwa manusia memiliki alat berpikir (tool of mind) yang dapat dipergunakan untuk membantu memecahkan masalah, memudahkan melakukan tindakan sesuai kapasitas alami, dan memperluas kemampuan (Moss dan Dahlberg, 2008).

Penerapan teori konstruktivisme dalam program kegiatan bermain AUD adalah: 1) anak memperoleh kesempatan luas dalam kegiatan pembelajaran guna mengembangkan potensinya; 2) pembelajaran dikaitkan dengan tingkat perkembangan potensial daripada perkembangan aktualnya; 3) program kegiatan bermain lebih diarahkan pada penggunaan strategi; 4) anak diberi kesempatan yang luas untuk mengintegrasikan pengetahuan deklaratif yang telah dipelaiari dengan pengetahuan prosedural untuk melakukan tugas dan memecahkan masalah; 5) proses belajar tidak hanya bersifat transferal tetapi merupakan ko-konstruksi. Guru hanya membantu tumbuhkembang anak.

Selain itu, pembelajaran yang terjadi harus dalam suasana kebebasan yang positif, kebebasan dalam pembentukan perilaku yang dimaknai secara positif konstruktif, yang secara langsung dikaitkan dengan tanggung jawab dan kesadaran akan kebebasan orang lain (Lieber, Butera, Hanson, Palmer, 2009). Jadi tidak dapat dipungkiri bahwa bermain dan permainan sangat potensial untuk mengembangkan potensi anak dalam bidang fisik, kognitif, afektif, dan social. Permainan adalah dunia anak yang sesungguhnya. Ia tumbuh dan berkembang menjadi manusia seutuhnya dalam dan melalui bermain dan permainan (Logue, 2007).

\section{Pendidikan Karakter}

Dalam mengembangkan model Unfold Circles, penulis juga menyadari bahwa untuk membangkitkan bakat alami AUD, sangat diperlukan membangun karakter anak melalui kegiatan nyata dan permainan. Selaras dengan imbauan dari menteri pendidikan bahwa pendidikan untuk memulai pendidikan karakter di usia dini, maka Ikatan Guru Taman Kanak-kanak Indonesia (IGTKI) bersama Diknas harus terus berupaya keras menciptakan generasi muda yang berakhlak mulia, dinamis, cerdas dan produktif (Hidayat, 2013). Pendidikan karakter bagi anak usia dini (AUD) memiliki makna yang lebih tinggi dari sekedar pendidikan moral, karena tidak hanya berkaitan dengan benar atau salah, akan tetapi lebih berfokus pada bagaimana cara menanamkan kebiasaan (habit) tetang segala perilaku yang baik dalam kehidupan. Dengan demikian, anak sejak dini sudah memiliki kesadaran dan pemahaman yang tinggi, serta kepedulian dan komitmen untuk menerapkan kebajikan dalam kehidupan sehari-hari. Karakter merupakan sifat alami bagi AUD untuk merespon situasi secara bermoral (Lewis, 2008) dan harus diwujudkan tindakan nyata melalui pembiasaan untuk berperilaku baik, bertutur kata sopan dan baik, jujur, bertanggung jawab, dan hormat kepada orang lain, terutama pada orang yang usianya lebih tua.

Pembentukan sejumlah perilaku positif merupakan salah satu tujuan utama pendidikan. Diknas mewajibkan 9 pilar karakter yang harus dibentuk dalam pembelajaran di PAUD, yaitu: 1) cinta Tuhan, bersyukur, dan cinta kebenaran; 2) kemandirian, disiplin, tanggung jawab; 3) jujur, amanah, berkata bijak; 4) sopan, hormat, patuh, pendengar yang baik; 5) dermawan, suka menolong, kerja sama; 6) percaya diri, kreatif, pantang menyerah; 7) baik, rendah hati; 8) 
kepemimpinan, keadilan; 9) toleransi, kedamaian, kedermawanan (Departemen Pendidikan Nasional, 2013).

Membangun ciri karakter yang kuat tidaklah mudah dan dibutuhkan keberanian serta kerja keras seumur hidup. Hal ini sejalan dengan ungkapan Aristotle bahwa karakter erat kaitannya dengan habit atau kebiasaan yang terus-menerus dipraktekkan dan diamalkan (Lewis, 2008). Kualitas-kualitas kemanusiaan yang menyangkut perilaku bukan bawaan lahir, tetapi merupakan hasil belajar. Pembentukan perilaku peserta didik PAUD membutuhkan metode dan strategi pembelajaran yang tidak tunggal. Model dan strategi yang dipilih harus mampu menempatkan tumbuh kembang kesadaran anak tentang dirinya menuju kematangan dan kedewasaan sebagai tujuan utama (Putra, 2012).

Dengan teori-teori yang mendasari pengembangan Unfold Circles, dikembangkan model BCCT dengan mengubah seting pembelajaran. Proses pembelajaran dirancang dengan mengembangkan tema dalam kurikulum generik PAUD menjadi subtema yang menarik dan konstektual bagi anak untuk mencapai kompetensi yang diharapkan dapat dikuasai AUD. Dengan mengembangkan BCCT menjadi model unfold Circles (model seting lingkaran berlipat; penilaian perkembangan peserta didik melalui pengamatan perilaku individu sebagai anggota dalam lingkaran-lingkaran kecil; dilanjutkan pengamatan pada seluruh peserta didik dalam lingkaran besar). Model ini menghadirkan satu pola, di mana dalam satu kegiatan main, area permainan dibagi menjadi 3 lingkaran besar, yang selanjutnya setiap lingkaran besar masih dibagi lagi menjadi 3 lingkaran kecil yang berisi 5 anak, dengan kegiatan main yang sama; rasio perbandingan guru/peserta didik adalah 1 guru/ 15 anak; dan pengembangan kompetensi, kecerdasan dan pembentukan karakter anak dikembangkan dalam sub-tema Rancangan Kegiatan Harian (RKH).

Dengan mengemas area permainan dan metode pembelajaran Unfold Circles, maka sangat diharapkan bahwa model ini mampu membuat AUD merasa enjoy learning walaupun mereka berada dalam kelas besar ( $>35$ peserta didik/kelas), mengembangkan dan meningkatkan kompetensi, kecerdasan dan karakter dasar AUD, serta mengembalikan fungsi hakiki PAUD sebagai 'taman yang indah untuk belajar melalui bermain'.

Berdasarkan kajian teori yang sudah dirumuskan, maka dirumuskan 2 hipotesis penelitian, yaitu: (H.1): Model Pembelajaran Unfold Circles mampu memberdayakan kemampuan dasar, kecerdasan dan karakter dasar AUD; (H.2): Model Pembelajaran Unfold Circles mampu mengembalikan fungsi hakiki dari PAUD sebagai 'taman yang indah untuk belajar melalui bermain'.

Fokus data penelitian ini lebih lanjut diarahkan untuk mencapai tujuan penelitian, yaitu: 1) memperoleh gambaran hasil penerapan Model Unfold Circles di wilayah yang berbeda, 2) memperoleh pembuktian bahwa model 'Unfold Circles' mampu mengembangkan dan meningkatkan kompetensi, kecerdasan dan karakter AUD, 3) memperoleh pembuktian bahwa penerapan model Unfold Circles mampu mengembalikan fungsi hakiki dari PAUD sebagai 'taman yang indah untuk belajar melalui bermain'.

\section{METODE}

Penelitian ini merupakan penelitian lanjutan dari penelitian-penelitian yang dilakukan sejak tahun 2008 tentang AUD. Penelitian ini dilaksanakan dengan 4 tahapan penelitian, yaitu 1) tahap eksplorasi, 2) tahap pengembangan, 3) tahap penerapan model, dan 4) tahap mindset transformation (yang dilaksanakan dengan seminar lokakarya model Unfold Circes yang merupakan tujuan akhir dari penelitian ini, yaitu meningkatkan kompetensi profesional guru PAUD).

Penelitian dilakukan dengan multi metode, yakni metode deskriptif kualitatif dan penelitian tindakan kelas (PTK). Untuk tahap eksplorasi, yang dilaksanakan pada 01 - 15 Maret 2014, peneliti menggunakan metode deskriptif kualitatif 
karena tahap ini masih dipengaruhi kuantitatif dalam menempatkan teori pada data yang diperoleh (Bungin, 2009). Pada tahap penerapan model (hasil refleksi teori), peneliti menggunakan PTK, yang merupakan model penelitian untuk mengembangkan teori sekaligus melaksanakannya dalam tindakan (Hatch, 2007)

Untuk tahap penerapan model dengan PTK, peneliti melaksanakan di PAUD Muslimat NU 12 malang (sebagai PAUD wilayah perkotaan) pada 27 Maret - 24 Mei 2014 dan PAUD Darussalam (PAUD wilayah pedesaan) di desa sumberpasir Kecamatan Pakis Kabupaten Malang pada 28 Mei - 26 Juli 2014, dengan subyek penelitian peserta didik TK kelas A. Selain kedua PAUD berada pada wilayah yang berbeda siuasi dan kondisinya, rasio perbandingan guru/peserta didik adalah 2 guru /45 anak.

Metode pengambilan data dilakukan dengan tahapan: 1) in-depth interview dan snowballing teknik dilaksanakan pada tahap eksplorasi, 2) reflektif teori pada tahap pengembangan model, 3) PTK dilaksanakan pada penerapan model, dan 4) lembar pengamatan dilaksanakan pada tahap mindset transformation. Rumusan hipotesis divalidasi dengan teknik triangulasi dari tiga sudut pandang yang berbeda, yaitu: peneliti, guru, dan siswa. Sebagai indikator pencapaian pengembangan dan peningkatan kompetensi, dan kecerdasan, digunakan skala penelitian Munandar dan Wutun (1999; dalam Bungin, 2009), sebagai berikut: 1 ) sangat baik: $>9.1$; 2) baik: 6.1-9;3) kurang berkembang: 3.16; dan 4) tidak berkembang: < 3. Sedangkan untuk peningkatan pengembangannya dengan indikator berikut: 1 ) sangat signifikan: $>2.1$; 2) signifikan: 1.1- 2; kurang signifikan: < 1; dan 4) tidak meningkat: 0 .

\section{HASIL DAN PEMBAHASAN}

\section{Tahap Eksplorasi}

Pada tahap ini, ditemukan bahwa kompetensi profesional guru PAUD Kota dan Kabupaten Malang masih rendah, tergambar sebaga berikut: 1) mindset guru PAUD bahwa mengajar di PAUD mudah dan dapat dilakukan tanpa persiapan;
2) Banyak guru PAUD masih lulusan SMA dan SMP; 3) para guru PAUD kurang mengikuti pelatihan (sebagian guru PAUD masih mempunyai gaji lebih rendah dari UMR); 4) faktor kuantitas guru tidak pernah diperhatikan oleh pengelola PAUD, guru mengajar lebih dari 35 peserta didik/kelas menimbulkan banyak masalah baru; dan 4) banyak PAUD yang melaksanakan proses pembelajaran di fasilitas umum, sehingga proses pembelajaran akan terganggu sewaktu-waktu ada kegiatan umum lainnya.

\section{Tahap Pengembangan}

Berdasarkan hasil temuan pada tahap eksplorasi, baik temuan dalam observasi maupun forum diskusi dan penelitian-penelitian sebelumnya, maka pada tahap ini semua data dianalisa dengan menggunakan reflektif teori. Data yang diperoleh meliputi data tentang pelaksanaan pembelajaran, strategi pembelajaran yang digunakan, kurikulum, alat peraga edukatif (APE) yang digunakan, kompetensi guru, lingkungan sekolah dan kharakteristik peserta didiknya, serta data mengenai permasalahan di PAUD dan harapan-harapan para gurunya. Hasil dari pengembangan adalah model Unfold Circles berbasis situasi dan kondisi PAUD. Dalam model Unfold Circles semua area permainan dalam dan luar ruangan dibuat sangat sederhana dan terbuka, dengan tetap mempertahankan karakteristik model BCCT asli. Perkembangan meliputi: 1) area main dalam satu kegiatan main dibagi menjadi tiga lingkaran besar berisi 15 peserta didik/lingkaran. Selanjutnya setiap lingkaran besar dibagi lagi menjadi tiga lingkaran kecil dengan 5 peserta didik/lingkaran kecil, 2) kegiatan main untuk lingkaran-lingkaran kecil dalam setiap lingkaran besar alah sama, 3) rasio perbandingan guru dan peserta didik adalah 1 guru/15 anak/ lingkaran besar, 4) satu tema dalam kurikulum dikembangkan untuk tiga kegiatan main yang dideskripsikan dalam rancangan kegiatan harian (RKH). 
Dengan penataan area permainan sederhana dan fleksibel, juga APE yang dapat dibuat sendiri dari bahan sekitar, maka sangat memungkinkan model Unfold Circles diterapkan pada semua PAUD dalam berbagai situasi dan kondisi, karena model ini tidak memerlukan lahan yang luas dan dana yang besar. Namun pelaksanaan model ini memerlukan: 1) kreatifitas tinggi dari guru dalam merancang RKH (yang mampu membentuk dan mengembangkan 9 pilar karakter dasar) dan APE; serta 2) kemampuan guru dalam mengendalikan sifat AUD yang mudah bosan dan selalu ingin tahu pada pada hal-hal yang baru.

\section{Tahap Penerapan Model}

Dalam penerapan model Unfold Circles, empat kompetensi dasar (berbahasa, kognitif, fisikmotorik, seni) dan sembian kecerdasan AUD (linguistic intelligence; logical intelligence; spatial intelligence; kinesthetic intelligence; musical intelligence, inter \& intra-personal intelligence; naturalistic intelligence dan existential intelligence) dapat dikembangkan dan ditingkatkan. Demikian juga dengan 9 pilar karakter dasar dapat dibentuk, yaitu: 1) cinta Tuhan, bersyukur, dan cinta kebenaran; 2) kemandirian, disiplin, tanggung jawab; 3) jujur, amanah, berkata bijak; 4) sopan, hormat, patuh, pendengar yang baik; 5) dermawan, suka menolong, kerjasama; 6) percaya diri, kreatif, pantang menyerah; 7) baik, rendah hati; 8) kepemimpinan, keadilan; 9) toleransi, kedamaian, kedermawanan.

\section{PAUD Perkotaan}

Dari 45 peserta didik, sebanyak 29 anak mengalami peningkatan secara sangat signifikan (64\%); sedangkan sebanyak 16 anak mengalami peningkatan secara signifikan (36\%).

Semua 45 peserta didik (100\%) mencapai indikator kemampuan dasar dan Kecerdasan jamak yang Berkembang sangat baik (nilai rerata >9.1); demikian juga dengan 9 karakter dasar, semuanya dapat berkembang sangat baik.

Dari 25 indikator kemampuan dasar, sebanyak 20 indikator dapat ditingkatkan secara sangat signifikan. Kemampuan yang mengalami peningkatan secara signifikan adalah: 1) menyelesaikan tugas dengan baik/fisik-motorik; 2) menyebut nama hasil kegiatan/bahasa; 3) kesempurnaan hasil kegiatan/fisik-motorik; 4) keberanian bertanya pada temannya/Interpersonal; 5) keberanian menceritakan pengalaman yang baru dilakukan/Bahasa.

\section{PAUD Pedesaan}

Dari putaran I dan II, peningkatan kecerdasan jamak dapat dideskripsikan sebagai berikut. Dari 45 peserta didik, sebanyak 11 peserta didik mengalami peningkatan kecerdasan jamak secara signifikan (27\%), sedangkan sisanya sebanyak 34 anak mengalami peningkatan kurang signifikan (73\%).

Semua 45 peserta didik mengalami peningkatan kemampuan dasar secara signifikan (100\%); hanya 1 indikator kemampuan dasar yang tidak mengalami peningkatan yaitu kesempurnaan hasil (fisik-motorik).

Karakter dasar berkembang dengan baik adalah: taqwa pada Tuhan, jujur, sopan, suka menolong, pantang menyerah, rendah hati, toleransi, empati; dan yang kurang berkembang adalah: mandiri, disiplin, bertanggung jawab, berkata sopan dan baik, hormat pada guru, patuh, menjadi pendengar yang baik.

Selain itu, penerapan model Unfold Circles dalam proses pembelajaran AUD menerima 2 macam hipotesis yang diajukan dan sekaligus menjawab 3 macam permasalahan yang diajukan dalam penelitian ini. Dengan terjawabnya 3 macam permasalahan yang diajukan, maka penerapan model Unfold Circles dalam proses pembelajaran AUD benar-benar telah mencerminkan AUD merasa enjoy learing. Sekaligus juga membuktikan bahwa model Unfold Circles dapat mengembalikan fungsi hakki PAUD sebagai 'taman yang indah untuk belajar melalui bermain' (learning by playing).

Hasil penelitian juga menguatkan teori Gardner dan Evangeline Haris Stefanakis, yang mengatakan bahwa AUD sudah dilengkapi dengan sejumlah kecerdasan majemuk (multiple 
intelligence) yang dapat berkembang melalui kondisi pembelajaran yang kondusif dan atraktif, yang semuanya sangat tergantung pada kreativitas guru (kompetensi profesional) dalam mengembangkan area permainan dan APE. Selain itu, hasil penelitian ini juga mendukung pernyataan Yuliani (2009) yang menyatakan bahwa di Indonesia kecerdasan spiritual AUD sangat menonjol.

Model Unfold Circles mempunyai beberapa keunggulan, yaitu ketuntasan tugas yang diemban peserta didik; tidak memerlukan dana besar dan lahan luas, serta mampu membentuk dan mengembangkan 9 pilar karakter dasar anak yang diwajibkan Diknas.

Adapun kelemahan model tampak ketika diterapkan pada peserta didik PAUD wilayah pedesaan, yang tampak jenuh ketika pembelajaran berlangsung dalam ruangan, Akan tetapi apa bila pembelajaran berlangsung di luar ruangan, maka mereka menjadi sangat antusias.

\section{Tahap Mindset Transformation}

Tahap ini direalisasikan dengan seminar lokakarya model pembelajaran Unfold Circles dan pembuatan APE dari bahan bekas dan lingkungan sekitar PAUD. Seminar lokakarya ini dilaksanakan pada 30-31 Agustus 2014 dengan 30 peserta guru PAUD kota dan Kabupaten Malang.

Secara keseluruhan, peserta sangat antusias dalam mengikuti kegiatan pemodelan dan praktik. Pelaksanaan praktik lebih mem- berikan contoh konkrit bagi peserta, sehingga mereka tampak lebih antusias dalam menanggapi pelaksanaan praktik. Antusiasme peserta juga ditunjukkan oleh oleh permintaan peserta agar kegiatan seperti ini dilakukan secara periodik.

\section{KESIMPULAN DAN SARAN Simpulan}

Dari hasil analisa data dan pembahasan, dapat disimpulkan bahwa model Unfold Circles secara valid dapat diterapkan pada PAUD wilayah perkotaan dan pedesaan, dalam berbagai situasi dan kondisi. Model ini juga mampu mengembangkan dan meningkatkan kompetensi, kecerdasan jamak, serta membentuk karakter dasar AUD. Selain itu, model ini juga mengembalikan fungsi hakiki PAUD sebagai 'taman yang indah bagi AUD untuk belajar melalui bermain'

\section{Saran}

Saran diberikan kepada yang berwenang dengan PAUD, seperti: 1) bagi pengembang PAUD, model Unfold Circles memberi kontribusi bagi pengembangan strategi pembelajaran AUD sesuai dengan situasi dan kondisi PAUD. Diharapkan mereka memberi referensi pelaksanaan Unfold Circles di seluruh PAUD di Indonesia; 2) bagi Ikatan Gutu Taman Kanakkanak Indonesia (IGTKI) penelitian ini menjadi referensi untuk diskusi perbaikan mutu pendidikan dan tenaga pendidik PAUD secara berkelanjutan.

\section{PUSTAKA ACUAN}

Aminatun, S. 2008. Pemanfaatan Monograf dan Batang Napier Sebagai Media Pembelajaran Anak Usia Dini. Jurnal Pendidikan Inovatif, vol. 3, no. 2, Maret 2008.

Baskett R, Bryant K, White W \& Rhoas K. 2006. Half-day to full-day Kindergarten: an analysis of educational change scores and demonstration of an educational research collaboration. Early Child Development and Care. 175: 419 - 30.

Bungin, B. 2009. Penelitian Kualitatif: Komunikasi, Ekonomi, Kebijakan Publik, Ekonomi, dan IImu Sosial Lainnya. Jakarta: Kencana.

Creative Center for Childhood Research and Training, inc. (CCCRT). (2006). Scafolding and assessing the play of young children, beyond centers \& circle time. Florida: 2746bWest Tharpe Street Tallahassee. Florida 32303 850.422.1080.

Chien, Nina C; Howes, Carollee; Burchinal, Margaret; Pianta, Robert; Bryant, Donna. 2010. 
Children classroom engagement and school readiness gains in prekindergarden. Child Development, 81, 1534 - 49. Doi:10.1111/j.1467-624.2010.01490.x.

Depdiknas. 2013. Kurikulum TK/RA: Pedoman Penyusunan Silabus. Jakarta: Direktorat Pendidikan YK dan SD.

Drzal E,V; Carenno C,M; Li-Grining C,P. 2008. A development perspective on full versus part-day Kindergarten and children's academic Trajectories trough fifth grade. Child Development. 79:957-78.

Guo, Y., Piasta, S.B., Justice, L.M. \& Kaderavek, J. N. 2010. Relations among preschool teachers' self-efficacy, classroom quality, and children's language and literacy gains. Teaching and Teacher Education, 26:1094-1103. Doi:10.1016/j.tate.2009.11.005.

Hatch, J Amos ed. (2007). Early Childhood Qualitative Research. London: Routledge.

Hedges, Helen (2014). Your children's working theories': Building and connecting understanding. Journal of Early Childhood Research. XII (1) 35-49. doi: 10.1177/1476718x13515417

Hidayat, S. 2013. Pengembangan Kurikulum 13. Bandung: Rosda.

Lestarini, Y .2013. Penerapan Model Pembelajaran BCCT untuk Meningkatkan Minat dan Aktivitas Belajar Anak Kelompok B TK BumiGora BPKBM NTB. Jurnal Penelitian Pasca Sarjana Undiksa. IX (3), 25-36.

Lewis, Barbara. 2008. Character Building Untuk Anak-anak (Being Your Best). Batam: Karisma Publishing.

Lieber, J., Butera, G., Hanson, M., Palmer, S .2009. Factors that influence the implementation of new preschool curriculum: Implications for professional development. Early Education and Development, 20, 456-81. Doi: 10.1080/10409280802506166.

Logue Mariy E. 2007. Early Childhood Learning Standard: Tools for Promoting Social and Academic Success in Kindergarten. ProQuest Education Journals. XXIX (1).

Lower, J. K. \& Cassidy, D. 2007. Child care work environments: The relationship with learning environments. Journal of Research in Childhood Education, 22, 189-204. Doi: 10.1080/ 02568540709594621.

Montessori, Maria. 2008. The Absorbent Mind. Yogjakarta: Pustaka Belajar.

Moss, P \& Dahlberg, G. 2008. Beyond Quality in Early Childhood Education and Care - Language of Evaluation. New Zealand, Journal of Teachers Work, $V(1, \mathrm{hlm}$. 03-12.

Putra, N. 2011. Pemberdayaan Keberagaman Anak Jalanan Untuk Meningkatkan Kualitas Hidup Masyarakat Kumuh di DKI Jakarta. Jakarta: Lembaga Penelitian IKIP Jakarta.

Rahman, Taufik. 2013. Implementasi Pendekatan BCCT Beyond Centers and Circle Time dalam Mengembangkan Kecerdasan Jamak (Multiple Intelligences) Anak Usia Dini. Unpublish Thesis S2. Surabaya: UNESA.

Sumarni, S. 2013. Influence of Social Development In Early Age Children. Prosiding Seminar Pendidikan Nasional. pp. 1422-1436. ISSN 978-602-95793-5-2.

Suratmi, N (2012). BCCT-I: Pengembangan Model Beyond Center Circle-Time Berbasis Situasi dan Kondisi PAUD. Jurnal Penelitian Pendidikan Universitas Negeri Malang. XXII (2), 125132.

Vartuli, S., Bolz, C., \& Wilson, C. 2014. A Learning Combination: Coaching with Class and The Project Approach. Early Childhood Research and Practice. Vol. 20, numbers 1 \& 2.

Yuliani, N. S. 2009. Pengembangan PAUD Berbasis keluarga: Mengembangkan Keterampilan Hidup Anak Usia Dini Melalui kecerdasan hati. Jakarta: Direktorat PAUD, Depdiknas. 
Jurnal Pendidikan dan Kebudayaan, Vol. 21, Nomor 2, Agustus 2015 